\title{
COMMENTS
}

\section{THE DETAINER SYSTEM AND THE RIGHT TO A SPEEDY TRIAL}

The sixth amendment to the Constitution provides in part that "in all criminal prosecutions the accused shall enjoy the right to a speedy ... trial." No constitutional guarantee has been the subject of less discussion: No federal statute effectively implements it; ${ }^{1}$ no great cases have been identified with it; ${ }^{2}$ no articles relating to it are found in the law reviews. ${ }^{3}$

The chief explanation for neglect of this guarantee is perhaps found in the conviction of the courts that since delay is usually in the interest of defendants, protection against it is not a necessary safeguard for them. 4 Prosecutors are thought to invariably share Bentham's view: "It is necessary that the punishment should be as near, in point of time, to the crime, as possible; because its impression upon the minds of men is weakened by distance; and because this distance adds to the uncertainty of its infliction, by affording fresh chances of escape."5

Where the right has not been implemented by statute, delays of incredible length both between the commission of an offense and the filing of a charge ${ }^{6}$ and between indictment and trial ${ }^{7}$ are tolerated by the courts.

1 The only nonconstitutional restriction on delay in trials in the federal courts is that found in FED. R. CRIM. P. 48(b), added in 1948: "If there is unnecessary delay in presenting the charge to a grand jury or in filing an information against a defendant who has been held to answer to the district court, or if there is unnecessary delay in bringing a defendant to trial, the court may dismiss the indictment, information, or complaint." See also D.C. CoDE ANN. § 23-104 (1961).

2 Petition of Provoo, 17 F.R.D. 183 (D. Md.), aff'd, 850 U.S. 857 (1955), the most important federal court pronouncement vindicating the right, contains a discussion of its history.

8 The writing on this subject has been confined almost entirely to student comments. E.g., Note, 57 Colum. L. REv. 846 (1957); Note, 64 Yale L.J. 1208 (1955). On the detainer system, see Note, 48 Colum. L. REv. 1190 (1948), and the symposium in Fed. Prob., July -Sept. 1945, pp. 1-28.

4 Cf. Heller, The Stxth Amendment 63 (1951): "[S]peed, once thought so vital when transportation beyond the seas threatened the accused in the American colonies and defendants were rarely permitted the assistance of proper legal advisers, is, indeed, not a primary consideration."

5 Bentham, Principles of Penal Law, in 1 Works 402 (1843).

- This topic is well treated in Note, 5 Stan. L. Rev. 95 (1952). See also Note, 102 U. PA. L. REv. 680 (1954). But see Harlow v. United States, 301 F.2d 361 (5th Cir. 1962); Hoopengarner v. United States, 270 F.2d 465 (6th Cir. 1959). People v. Saccenti, 
The practice, countenanced by federal law and the statutes of most states, of allowing prosecutors to enter a nolle prosequi without consent of defendants is also a fruitful cause of delay where defendants are later reindicted on the same charge. ${ }^{8}$ Cases involving multiple indictments also generate delays, ${ }^{9}$ where trial of early indictments is postponed until later charges are disposed of. Delays between conviction and sentencing may also frequently develop, ${ }^{10}$ as may delays due to failure to accord expeditious handling to defendants' appeals. ${ }^{11}$

18 App. Div. 2d 311, 239 N.Y.S.2d 725 (1963), rev'd on other grounds, 14 N.Y.2d 1, 196 N.E.2d 885 (1964) is a leading case extending the right to speedy trial to delay in indictment. The dissenting opinion in People v. Tower, 18 App. Div. 2d 284, 287, 239 N.Y.S.2d 212, 214 (1963), would extend the right to unprecedented lengths by holding that failure to promptly arrest and bring to trial a person whose whereabouts are known to the authorities can supply grounds for dismissing a pending indictment.

7 The leading Supreme Court cases include Pollard v. United States, 352 U.S. 354 (1957); Petition of Provoo, 17 F.R.D. 183 (D. Md. 1955), aff'd, 350 U.S. 857 (1955). See FED. R. CRIM. P. 48(b), supra note 1; Smith v. United States, 360 U.S. 1, 10 (1959) (dictum); Frankel v. Woodrough, 7 F.2d 796 (8th Cir. 1925).

8 See Annot., 30 A.L.R.2d 462 (1953); Comment, 4 STAN. L. REv. 537 (1952); 214 L.T. 108 (1952). Recent cases include People ex rel. Elliott v. Covelli, 415 Ill. 79, 112 N.E.2d 156 (1953); People v. Watson, 394 Ill. 177, 68 N.E.2d 265, cert. denied, 329 U.S. 769 (1946); State v. Murray, 222 La. 950, 64 So. 2d 230 (1953). People v. Wilson, 8 N.Y.2d 391, 171 N.E.2d 310, 208 N.Y.S.2d 963, (1960), applies the right to speedy trial to this stage.

9 See Comment, 4 Stan. L. REv. 537, 539 (1952). See also Beavers v. Haubert, 198 U.S. 77, 86-87 (1905); Frankel v. Woodrough, 7 F.2d 796, 798 (8th Cir. 1925). Federal prosecutors are said to tend to bring prisoners to trial at the place of arrest, even if older charges are pending elsewhere, though lesser charges are usually dismissed.

10 Pollard v. United States, 352 U.S. 354 (1957); Kaye v. United States, 235 F.2d 187 (6th Cir. 1956); Annot., 97 A.L.R. 802 (1935); Annot., 3 A.L.R. 1003 (1919). FED. R. Crm. P. 32(a) provides: "Sentence shall be imposed without unreasonable delay. Pending sentence the court may commit the defendant or continue or alter the bail." Representative recent cases dealing with state statutes includes Helton v. State, 106 So. 2d 79 (Fla. 1958); People ex rel. Harty v. Fay, 10 N.Y.2d 374, 179 N.E.2d 483, 223 N.Y.S.2d 968 (1961). See also Butts v. Commonwealth, 145 Va. 800, 133 S.E. 764 (1926). Federal prosecutors are said to frequently delay sentencing where prisoners have agreed to testify in other pending proceedings until after their testimony is forthcoming. $C f$. United States v. Worcester, 190 F. Supp. 548 (D. Mass. 1960). Use of such delay to enforce restitution is said to be rare, though probation may be used for this purpose.

11 See generally Orfield, Criminal ApPeals IN AMERICA (1939); Orfield, Improving Procedure on Judgment and Appeal in Federal Criminal Cases, 27 MinN. L. REv. 169 (1943), and the interesting notes on foreign practice in 4 CAN. BAR REv. 412 (1926); 72 Sol. J. 92 (1928). See also Ward v. United States, 76 Sup. Ct. 1063 (Frankfurter, Circuit Justice, 1953). A firm approach to one cause of appellate delay is found in MD. Const. art. 4, \& 15: "[I]n every case an opinion in writing shall be filed within three months after the argument or submission of the cause ...." The provision, however, has been held to be directory only. McCall's Ferry Power Co. v. Price, 108 Md. 96, 69 Atl. 832 (1908). Compare Drews v. Maryland, No. 3 on the U.S. Supreme Court's 1963 docket, pending (as of March 17, 1964) in that Court without grant or denial of certiorari since March 23, 1961. 
It is clear, however, that denial of the right to speedy trial promotes a variety of prejudices to the defendant including psychological anguish, loss of earning capacity ${ }^{12}$ and coercion of conduct. ${ }^{13}$ More basic is the difficulty created for the defendant put to the proof of his case years after the event, when memories have faded and witnesses have vanished.14 An additional form of prejudice flowing from protracted delay falls upon incarcerated prisoners. The placing of "detainers" (formal requests for notification of a prisoner's release date) on prisoners wanted for trial in another jurisdiction can operate to subject them to a variety of severe sanctions, from denial of "trusty" status to inadequate preparation for release, and, in many instances, denial of parole. ${ }^{15}$

The evil effects of an unmodified detainer system were recently graphically summarized by an Ohio Common Pleas Court:

Delaying the indictment and the trial on one offense after another, until time is served on each consecutively, and served under circumstances described, is a denial of a speedy trial. It requires no intellectual gymnastics to see that such a plan designed to indefinitely extend the punishment and postpone the liberty of an individual is a violation of constitutional rights.

The exercise of such control over a form of installment punishment, compounded by detainers, is an usurpation of the power of the court, of the jury, and of the parole board to determine guilt and punishment under the indeterminate sentence law. Whether consecutive or concurrent sentences should be imposed for more than one offense rests exclusively with the court, and it cannot be assumed by any other agency. ${ }^{16}$

12 The law does not usually protect against such forms of prejudice. In United States ex rel. Von Gseh v. Fay, 313 F.2d 620, 624 (2d Cir. 1963), the court, in declining to reverse a conviction where there was a forty-three month delay between indictment and trial due to departure of a prosecution witness from the country, observed: "We do not think that Von Cseh's general allegations regarding his inability to maintain gainful employment or regarding his mental anguish or that of his family present the type of prejudice contemplated by the fourteenth amendment. It is not the purpose of the due process clause to defend an accused against public opprobrium. So far as this case is concerned, it is addressed only to guaranteeing that the issues were not unfairly determined by reason of the long delay. Cf. Ullmann v. United States, 350 U.S. 422,430 (1956)."

13 Both delay in bringing charges and delay in sentencing can serve as a tool with which to coerce desired conduct from prospective defendants and prisoners, as can use of the nolle prosequi device.

14 Prosecutors, too, are prejudiced by delay, but the relative injury to the adversaries varies from case to case. Defendants may usually be assumed to be less well equipped to gather and preserve evidence; this is especially likely when they have been incarcerated on another charge during the intervening years. See Note, 57 Colum. L. REv. 846 (1957).

15 See the symposium in 9 Fed. Prob., supra note 3 and Note, 48 Colum. L. Rev. 1190 (1948).

16 State v. Milner, 78 Ohio L. Abs. 285, 288, 149 N.E.2d 189 (C.P. 1958). 
These evils are not of great seriousness on the intrastate level. Most states have statutory provisions requiring defendants to be brought to trial within a specified period of time after the charge or indictment.17 State courts are generally willing to consider other pending charges as a factor in sentencing. ${ }^{18}$

Much more serious problems are presented when prisoners are demanded by the authorities of another jurisdiction, state or federal. These problems are the subject matter of this paper, which shall consider the extent to which authorities are obliged, by constitution or statute, to seek delivery or temporarily yield custody of prisoners for trial prior to the expiration of their sentences under accomplished convictions. Included is a discussion of the provisions of the Agreement on Detainers contained in the Council of State Governments Suggested State Legislation Program for 1958.19

17 The states without speedy trial statutes were, as of 1963, Alabama, Connecticut, Maryland, Massachusetts, Michigan, Mississippi, New Hampshire, New Mexico and Rhode Island. The states lacking constitutional provisions included Nevada and New York. In addition, Massachusetts, New Hampshire and North Carolina had constitutional provisions couched in the language of the Magna Charta; other states construed similar provisions to confer a right to speedy trial. See Note, 57 Colum. L. REv. at $847 \mathrm{nn} .7-8$ (1957). With few exceptions, speedy trial statutes have been held to extend to trial of prisoners incarcerated in the same jurisdiction. See, e.g., People v. Prosser, 309 N.Y. 353, 130 N.E.2d 891 (1935). But see Wedmore v. State, 235 Ind. 34I, 133 N.E.2d 842 (1956); Shafer v. State, 43 Ohio App. 493, 183 N.E. 774 (1932), holding that no duty to demand prisoners for trial exists. The Shafer case was distinguished in State v. Milner, 78 Ohio L. Abs. 285, 149 N.E.2d 189 (G.P. 1958), and State v. Waites, 82 Ohio L. Abs. 356, 163 N.E.2d 195 (Munic. Ct. Akron 1959), on the basis that in Shafer, the detainer was based on an indictment rather than merely on affidavits.

State courts, moreover, have generally been liberal in dispensing with the requirement that defendants demand trials in cases where prisoners are involved, recognizing that lack of access to friends and legal counsel will operate to make such demand unlikely. Ex parte State ex rel. Attorney Gen., 255 Ala. 443, 52 So. 2d 158 (195I) (12 year imprisonment); Smith v. State, 146 S.W.2d 158 (Ark. 1941); Arrowsmith v. State, 131 Tenn. 480, 175 S.W. 545 (1915); cf. United States v. Chase, 135 F. Supp. 230 (N.D. IIl. 1955) (indictment dismissed after twenty-year period). But see Hottle v. District Court, 233 Iowa 904, 11 N.W.2d 30 (1943); Harris v. State, 194 Md. 288, 71 A.2d 36 (1950) (dismissal of indictment denied after five-year period); cf. United States v. Alagia, 17 F.R.D. 15 (D. Del. 1955) (dismissal of indictment denied after three-year period).

18 It may be "widespread practice for the judges of the high courts, when they formulate their sentences, to take into account pending charges which are admitted, and for prosecuting attorneys in the city courts to nol-pros the petty charges in view of the substantial sentence of the higher court." Hincks, The Need for Comity in Criminal Administration, 9 Fed. Prob., July-Sept. 1945, p. 5. FED. R. CRIM. P. 20 provides a partial analogue in the federal system. It makes consolidation for sentencing on charges in different districts possible where a guilty plea has been entered, the defendant consents to the procedure and the prosecutor does not object. Since consolidation for trial is not provided for, guilty pleas to obtain the benefits of concurrent sentencing are encouraged. See generally HART \& WECHSLER, THE FEDERAL COURTS AND THE FEDERAL SYSTEM 1106 (1953), and authorities cited therein.

19 Council of State Governments, Suggested State Legislation 78-85 (1957). 
Necessary appreciation of speedy trial problems raised by the detainer system cannot be gained apart from an understanding of the sources from which these problems spring. The most obvious of these sources is the double jeopardy situation typified by Bartkus v. Illinois. ${ }^{20}$ Probation and parole violations also raise problems where the paroling state places a detainer on prisoners incarcerated by another jurisdiction as a result of the crime which constituted their parole violation. ${ }^{21}$ Unenlightened parole systems may make such detainers bear heavily on prisoners, but they do not raise true speedy trial problems, save where the defendant is surrendered to or captured by the paroling state in advance of trial.22

More important as a cause of federal-state problems in this area are the broad "catch-all" federal criminal statutes, which frequently overlap state crimes: the Dyer Act relating to interstate transportation of stolen motor vehicles; ${ }^{23}$ the various federal firearms statutes; ${ }^{24}$ the Fugitive Felon Acts; ${ }^{25}$ and the various statutes relating to narcotics, ${ }^{26}$ gambling ${ }^{27}$ and the "white slave" traffic. 28 The existence of simultaneous criminal charges in different states results less from the nature of state statutes than from the nature of the crimes prohibited. The "chain-type" offense, that perpetuated by the itinerant hold-up man or bad check passer, gives rise to the most frequent conflicting demands for custody of prisoners.

20359 U.S. 121 (1959). Compare Donnelly, Goldstein \& Schwartz, Criminal LaW 389-99 (1962), and the Justice Department directive there cited; $c f$. MODEL PENAL CODE $\S 1.10$ (Proposed Final Draft, 1962).

21 See Note, 48 Colum. L. Rev. 1191 (1948).

22 Id. at 1204-06. The Federal Parole Board has recently (beginning in 1955) permitted parole to prisoners subject to detainers, $\mathbf{3 5 6}$ such paroles being granted in 1961 . The parole decisions are "made on the assumption that incarceration will not follow." See United States Board of Parole, Annual Report 7-8 (1961). Parole to detained prisoners would appear to be authorized by 18 U.S.G. $\$ 4164$ (1958).

23 Nat'l Motor Vehicle Theft Act (Dyer Act), 18 U.S.C. $\$ \S 10,2311-13$ (1958).

24 Federal Firearms Act, 52 Stat. 1250 (1938), as amended, 15 U.S.C. $\$$ 901-09 (1958). 2518 U.S.C. $\$ 1073$ (1958).

26 Narcotic Control Act of 1956, 70 Stat. 567, 8 U.S.C. $\$ \$ 1182,1251$, 18 U.S.C. $\S \S 1401-07,21$ U.S.C. $\$ \S 174,176 \mathrm{a}, 176 \mathrm{~b}, 184 \mathrm{a}, 198,26$ U.S.C. $\$ \S 4744,4755,4774,7237$, 7607, 7608 (1958); Narcotic Drugs Import \& Export Act, 35 Stat. 614 (1909), as amended, 21 U.S.C. $\S \S 171,173-85$ (1958); Opium Poppy Control Act of 1942, 56 Stat. 1405, as amended, 21 U.S.C. $\$ \S 188-188$ n. (1958); 24 Stat. 409 (1887), as amended, 21 U.S.C. §§ 191-93 (1958); 46 Stat. 587, as amended, 21 U.S.G. \$§ 197-98 (1958).

2764 Stat. 1134 (1951), as amended, 15 U.S.C. $\$$ 1171-78 (1962).

28 White Slave Law (Mann Act), 18 U.S.C. $\$ \$ 2421-24$ (1958). Many of these statutes have been criticized as overly broad, but their existence raises problems beyond those presented in reference to speedy trial, and an appraisal of their substance is beyond the scope of this paper. See Allen, Kenison, Willens \& Schwartz, Role of the Federal, State, and Local Governments in the Administration of Criminal Justice: A Panel, 1961 A.B.A. CRIM. LAW SECr. 30 (1961); Schwartz, Federal Criminal Jurisdiction and Prosecutors' Discretion, 13 LAw \& Contemp. Prob. 64 (1948). 
However, the problem is not so acute as that presented by federal-state conflict.

The number of persons convicted each year of federal offenses is a small fraction of the number incarcerated on state charges, ${ }^{29}$ but the federal government appears to account for a disproportionate share of the number of detainers filed at state prisons. Thus of ninety-six detainers filed at a leading Illinois prison in 1963, fifty-two were filed by federal officers and forty-four by other states. If parole violation and federal immigration detainers are subtracted, twenty federal and twenty state detainers remain. ${ }^{30}$ Whether the relatively high number of federal detainers results from jurisdictional overlap in defining substantive offenses, from differences in policy relating to the filing of detainers, or from the greater seriousness of federal crimes is not clear. However, the last explanation is implausible since the federal "trip-wire" offenses usually carry smaller penalties than the state offenses with which they overlap. ${ }^{31}$

Whether the prosecutor represents the federal government or the state, so long as a conventional detainer system continues to operate there appears to be little leverage to hasten final action on a charge pending against a prisoner incarcerated in another jurisdiction. "The prosecuting attorney who filed the charges knows that the prisoner can be found when he is wanted and that all he has to do is have the sheriff call at the institution the date the prisoner is to be discharged and take him into custody. Consequently he puts the case at the bottom of the docket and forgets about it . ..."32 Moreover the prosecuting attorney has little motivation to press his charges when the defendant is already incarcerated, save where there is danger that prosecution evidence will be lost. The possibility of the imposition of concurrent sentences may actually deter prosecutorial action once the detainer is filed:

29 See Schwartz, supra note 28.

30 Letter from Arthur V. Huffman, Illinois State Criminologist, to the University of Chicago Law Review, March 10, 1964, on file in University of Chicago Law Library. For older, but closely parallel figures for a leading Michigan prison, see Heyns, The Detainer in a State Correctional System, 9 Fed. Prob., July-Sept. 1945, p. 13. The Illinois statistics indicate that as of March 10, 1964, 4.36 per cent of the prisoners had federal or out-of-state detainers on file against them.

31 Fugitive Felon Act, 18 U.S.C. \$ 1073 (1958) (five yrs., \$5000); Gambling, 64 Stat. 1135 (1951), 15 U.S.C. \$ 1176 (1958) (two yrs. \$5000); Narcotic Control Act of 1956, 70 Stat. 567, 18 U.S.C. $\$ 1403$ (1958) (two-five yrs., \$5000), 21 U.S.C. § 174 (1958) (five-twenty yrs., $\$ 20,000$ ), 21 U.S.C. $\S 176(b)$ (1958) (up to death); National Motor Vehicle Theft Act (Dyer Act) $\S \S 1,3,18$ U.S.C. $\$ 2312$ (1958) (five yrs., $\$ 5000$ ); White Slave Act (Mann Act) $\S \S 1,4,6,18$ U.S.C. $\$ 2421$ (1958) (five yrs., \$5000), $\$ 2423$ (1958) (ten yrs., $\$ 10,000$ ), $\S 2424$ (1958) (two yrs., $\$ 2000$ ).

32 Bennett, The Correctional Administrator Views Detainers, 9 Fed. Prob., JulySept. 1945, p. 9. 
Prosecutors generally prefer to adopt a wait-and-see attitude concerning trial of prisoners. If the defendant is forced to serve a full (and long) sentence, the prosecutor will probably decide not to try him on the pending charge. If, however, the defendant is paroled, then he may face trial. Moreover, the state is concerned lest the accused's sentences run concurrently if he is accorded prompt trial and convicted.33

Finally, the practical expense and risk of transporting a prisoner from the place of incarceration to the trial may reduce either the inclination of the prosecutor to press his charge or the willingness of the prison official to release the prisoner. ${ }^{34}$

\section{Trial of State Prisoners Under Federal Charges}

The power of federal authorities to obtain custody of state prisoners by compulsory proceeding was restricted by the Supreme Court as early as 1807. In Ex parte Bollman, ${ }^{35}$ the Court held that federal courts could not interfere with state court proceedings once the jurisdiction of state courts had attached. In Ex parte Dorr, ${ }^{36}$ the Court declined to bring before a federal court a state prisoner convicted under an unconstitutional statute. That decision has been qualified by the habeas corpus act of 186737 which allows federal habeas corpus to run against the states "where any person may be restrained of his or her liberty in violation of the constitution." However, the act provides no basis for requiring the surrender for trial of validly convicted state prisoners to prevent delayed federal prosecution. Continued detention impairs no constitutional right and any prejudice to the prisoner results from federal, not state, action.

The fact that a federal court may lack the power to compel surrender of prisoners does not preclude their voluntary surrender by a state. Even though the provisions of the Uniform Criminal Extradition Act ${ }^{38}$ are not part of federal law and relate in terms only to the surrender of

33 Note, 57 ColuM. L. REv. 846, 865 n.131 (1957).

34 See, e.g., Application of Melton, 342 P.2d 571 (Okla. Crim. App. 1959).

358 U.S. (4 Cranch.) 75, 97 (1807): "The state courts are not, in any sense of the word, inferior courts, except in the particular cases in which an appeal lies from their judgment to this court; and in these cases, the mode of proceeding is particularly prescribed, and is not by habeas corpus. They are not inferior courts, because they emanate from a different authority, and are the creatures of a distinct government."

3644 U.S. (3 How.) 103 (1845). The Court relied on $\S 14$ of the Judiciary Act of 1789, 1 Stat, 82: "Provided, that writs of habeas corpus shall in no case extend to prisoners in gaol, unless ... they are in custody, under ... the authority of the United States, or are committed for trial before some court of the same, or are necessary to be brought into court to testify."

3714 Stat. 385 (1867), as amended, 28 U.S.C. \$ 2241(c)(3) (1958).

38 UnIform Criminal Extradition ACr, 9 U.L.A. at 258 (1957). 
prisoners by states to other states, state officials would seem to possess the inherent authority to surrender prisoners temporarily to federal officers for trial. ${ }^{39}$ Though the act was said to be necessary to remove previous doubt concerning the return to the imprisoning state of a prisoner extradited elsewhere to stand trial, ${ }^{40}$ its inapplicability to federal-state relations should not bar surrender of state prisoners to federal courts. ${ }^{41}$

There appears to be no substantial constitutional obligation for federal prosecutors to hasten the trials of defendants lodged in state prisons. The restraints imposed upon the federal courts by the sixth amendment and the Supreme Court's supervisory power over the administration of federal justice are minimal. It has consistently been held that the burden of demanding trial is placed upon federal defendants. ${ }^{42}$ Even incarceration is not usually sufficient to relieve defendants of that burden..$^{43}$ Delays of seven years have been held to be not inconsistent with the sixth amendment provision, 44 which is applied ordinarily only to purposeful delays ${ }^{45}$ or delays which seriously impair the capacity of defendants to present evidence. ${ }^{46}$ Even when they have afforded relief for violations of the constitutional right, the courts have been reluctant to dismiss, and have instead granted mandamus to require prosecutors to set cases for trial ${ }^{47}$ or allowed conditional dismissals ${ }^{48}$ or adjusted court calendars. ${ }^{49}$ In one recent case, prejudice resulting from a defense witness' absence when a case was finally set for trial was cured by excluding all oral testimony on the point at issue, on the theory that resort to written records coupled

39 See Note, 48 Colum. L. REv. 1190, 1201-05 (1948). Lower courts have taken this view. See, e.g., Wall v. Hudspeth, 108 F.2d 865 (10th Cir. 1940).

40 Note, 48 Colum. L. Rev. 1190, 1201 n.75 (1948).

41 Cf. Taylor v. United States, 238 F.2d 259 (D.C. Cir. 1956).

42 E.g., United States v. Fouts, 166 F. Supp. 38 (S.D. Ohio 1958), aff'd, 258 F.2d 402 (6th Cir.), cert. denied, 358 U.S. 884 (1958).

43 But compare the cases cited at Note, 57 Colum. L. Rev. 846, 855 nn.58-59 (1957).

44 United States v. Research Foundation, 155 F. Supp. 650 (S.D.N.Y. 1957) (case set for trial after seven years). Compare United States v. Dillon, 183 F. Supp. 541 (S.D.N.Y. 1960) (case dismissed after eight years).

45 Compare Pollard v. United States, 352 U.S. 354 (1957), with Petition of Provoo, 17 F.R.D. 183 (D. Md.), aff'd, 350 U.S. 857 (1955).

46 Compare Taylor v. United States, 238 F.2d 259 (D.C. Cir. 1956), with United States v. Van Allen, 288 F.2d 825 (2d Cir. 1961) (indictment at end of limitations period, seven year delay until trial).

47 Frankel v. Woodrough, 7 F.2d 796 (8th Cir. 1925). This approach, curiously, is applauded in 108 U. PA. L. REv. 414 (1960); Note, 64 YALE L.J. 1208 (1955). The difficulty with remedies other than dismissal of the charge is that their use gives prosecutors nothing to lose by delay.

48 See United States v. Kovacs, 150 F. Supp. 301 (E.D.N.Y. 1957).

49 United States v. Research Foundation, 155 F. Supp. 650 (S.D.N.Y. 1957). 
with a burden on the government to show their lack of ambiguity was sufficient to protect the defendant.50

Rule 48(b) of the Federal Rules of Criminal Procedure ${ }^{51}$ has been rarely applied by the courts. ${ }^{52} \mathrm{~A}$ threat of dismissal in a case involving a delay of fourteen months represents the strongest use of the rule. ${ }^{.3}$ Moreover, a preponderance of cases reject suggestions that either the constitution or Rule 48(b) imposes an obligation on federal authorities to seek delivery of prisoners from states. ${ }^{54}$ Taylor $v$. United States ${ }^{55}$ is one of the few contrary cases. There the prisoner was indicted four years after committing the federal offense. Two more years were allowed to pass before the federal authorities sought his temporary surrender by the state. The state granted custody. The Court of Appeals for the D.C. Circuit, in dismissing the charge, held that the federal rule requiring prisoners to demand trial was inapplicable since the prisoner had no notice of the federal indictment. The court also strongly stressed the possibility of serious prejudice to the prisoner where the evidence disclosed only a "weak" case. ${ }^{56}$ The result of the case was rested upon this cumulation of factors. Taylor was thus readily distinguished by a district court in United States $v$. Fouts ${ }^{57}$ where the existence of stronger evidence of guilt and the failure of the state prisoner to demand trial despite notice of the federal indictment were held to require an opposite result.

Until the Supreme Court more fully develops adequate standards for implementation of the sixth amendment speedy trial guarantee and Rule 48(b), and until federal enactment of the Agreement on Detainers is forthcoming, federal trial courts will remain confined in their ability

50 United States v. Shelton, 211 F. Supp. 869 (D.D.C. 1962).

51 Supra note 1 .

62 See the annotations to FED. R. CRIM. P. 48(b).

53 United States v. Kovacs, 150 F. Supp. 301 (S.D.N.Y. 1957).

54 Cited as the leading case in this area is Nolan v. United States, 163 F.2d 768 (8th Cir.), cert. denied, 333 U.S. 846 (1947), criticized 61 HARv. L. REv. 706 (1948). The case was followed in Morland v. United States, 193 F.2d 297 (10th Cir. 1951); De Maris v. United States, 187 F. Supp. 273 (S.D. Ind. 1960); United States v. Fouts, I66 F: Supp. 38 (S.D. Ohio 1958), aff'd, 258 F.2d 402 (6th Cir.), cert. denied, 358 U.S. 884 (1958); United States v. Jackson, 134 F. Supp. 872 (E.D. Ky. 1955). In Wzesinski v. Amos, 143 F. Supp. 585 (N.D. Ind. 1956), the court held that a prisoner who had been released from a state penitentiary after having been wrongfully imprisoned for seven years on a life sentence had not been deprived of a right to speedy trial on pre-existing federal charges despite the failure of federal authorities to seek his delivery. The court relied upon an Indiana statute barring the temporary surrender of life prisoners.

55238 F.2d 259 (D.C. Cir. 1956).

56 Id. at 262.

67166 F. Supp. 38 (S.D. Ohio), affd, 258 F.2d 402 (6th Cir.), cert. denied, 358 U.S. 884 (1958). 
to mitigate the abuses of the detainer system by requiring demands for or release of state prisoners for federal trial.

\section{Trial of Federal Prisoners Under State Charges}

The restriction of the power of state authorities to obtain release of federal prisoners for trial closely parallels the restriction of federal power over state authorities in the field. The case of Ableman v. Booth ${ }^{58}$ established that a state could not, by habeas corpus, bring a federal prisoner into its courts, without consent of the federal government, prior to expiration of his term. The jurisdiction of the federal court was held to attach until its processes, including imprisonment, were complete. The holding of that case has been qualified only as to bailed or paroled prisoners. In Hebert $v$. Louisiana, ${ }^{59}$ the Court rejected the contention that a federal prisoner out on bail was protected against state prosecution: "Certainly if the United States was not objecting, the fact that the accused were thus on bail ... presented no obstacle to the arrest under the process of the state court as a means of acquiring jurisdiction of their persons." 60 Hebert and later lower court cases ${ }^{61}$ also took the view that only the federal government itself had the right to prevent trial of its probationers and bailed prisoners, and that absent objection by the government, a defendant subject to the jurisdiction of a federal court in a pending proceeding had no remedy against state prosecution. The Court of Appeals for the Tenth Circuit departed from this position in Grant v. Guernsey ${ }^{62}$ and held that a probationer could obtain habeas corpus to prevent trial on a state charge where the federal government had not expressly consented to its being brought.

While it remains clear that a state cannot compel delivery of a federal prisoner for state trial, the case of Ponzi, v. Fessenden ${ }^{63}$ just as clearly established the authority of the Attorney General, apart from statute, to surrender prisoners temporarily so that they might stand trial in state courts. The Court noted that federal statutes authorizing temporary release of federal prisoners to give evidence in federal courts or be tried on other federal charges had been held not to violate orders of commitment ${ }^{6 t}$ and reasoned by analogy that surrender to state authorities like-

5862 U.S. (21 How.) 506 (1858).

59272 U.S. 312 (1926).

$60 \mathrm{Id}$. at 316.

61 Ex parte Marrin, 164 Fed. 631 (E.D.N.Y. 1908); In re Fox, 51 Fed. 427 (N.D. Cal. 1892); Mackin v. People, 8 N.E. 178 (Ill. 1886).

6263 F.2d 163 (10th Cir. 1933); 33 Colum. L. REv. 918 (1933). See generally Note, 48 Colum. L. Rev. 1190 (1948).

63258 U.S. 254 (1922).

64 Id. at 261, citing Ex parte Bollman, 8 U.S. (4 Cranch) 75, 98 (1807). The Ponzi 
wise should not be held to do so. As for statutes requiring federal authorities to keep prisoners in custody, the Court held that temporary surrender to state authorities did not violate this obligation ${ }^{65}$ and suggested that prisoners remaining in the formal custody of federal marshals might nonetheless be considered sufficiently within state jurisdiction to permit trial where a full opportunity for defense was provided. ${ }^{66}$

The rule of the Ponzi case was codified as section 4085 of the Criminal Code: ${ }^{67}$

Whenever any federal prisoner has been indicted, informed against, or convicted of a felony in a court of record of any State or the District of Columbia, the Attorney General shall, if he finds it in the public interest to do so, upon the request of the Governor or Executive authority thereof, and upon the presentation of a certified copy ... cause such person, prior to his release, to be transferred to a penal or correctional institution within such State or District.

Courts have frequently had occasion to repel efforts by prisoners to prevent their delivery to authorities of a state prior to expiration of their federal prison terms through application of this statute. ${ }^{68}$ But its pro-

Court qualified its position by adding that surrender was proper "provided it does not prevent enforcement of the sentence of the federal courts or endanger the prisoner." 258 U.S. at 263. Cited at this point was Logan v. United States, 144 U.S. 263 (1892), a case involving indictment of members of a lynch mob under the Civil Rights Act, where it was held that the right of federal prisoners to protection from lawless violence was a right protected by the act. Cf. Kyle v. United States, 211 F.2d 912 (9th Cir. 1954), where the possibility that a prisoner might escape was said to constitute possible justification for failure of federal authorities to transport a federal prisoner to stand trial on a federal charge in another district.

65258 U.S. at 264.

66 Id. at 265-66. In spite of the fact that the authority to surrender recognized in Ponzi facilitates a speedy trial, the Court's decision in that case was quite clearly not motivated by solicitude for defendants: "Delay in the trial of accused persons greatly aids the guilty to escape because witnesses disappear, their memory becomes less accurate and time lessens the vigor of officials charged with the duty of prosecution. If a plea of guilty and imprisonment for one offence is to postpone trial on many others, it furnishes the criminal an opportunity to avoid the full expiation of his crimes. . . . Nor ... is there any difficulty in respect to the execution of a second sentence. It can be made to commence when the first terminates." Id. at 264-65. The decision was regarded by the Court primarily as a means of dealing more effectively with multiple offenders seeking to evade punishment, with "the old-timer who . .. will plead guilty only to what he thinks is the lesser charge or the one which will give him 'the easiest go' in the hope that before the end of his sentence there will be less chance that he can be convicted of the more serious offense." Bennett, The Correctional Administrator Views Detainers, 9 Fed. Prob. July-Sept. 1945, p. 9. But the Ponzi decision was viewed as an aid to prisoners by state courts. See In re Berman, 80 F.2d 361 (7th Cir. 1935), cert. denied, 298 U.S. 660 (1936).

6718 U.S.C. § 4085(a) (1958).

08 E.g., Chapman v. Scott, 10 F.2d 156 (D. Conn. 1925), aff'd, 10 F.2d 690 (2d Cir.), 
visions have been of little effect in promoting speedy trials. Release of prisoners remains in the discretion of the Attorney General. ${ }^{69}$ Moreover, a request by the state authorities is necessary to bring the section into operation.

The extent to which states may be obligated to attempt to secure the delivery of federal prisoners for trial is a matter which would seem to turn chiefly on their own statutes and constitutions. It is established, at least for the time being, that the sixth amendment is not directly binding on the states nor is it made binding upon them, in haec verba, by the fourteenth amendment. This is the teaching of Gaines $v$. Washington, ${ }^{70}$ a case involving the amendment's "public trial" provision, and of numerous subsequent lower court decisions relating to speedy trial. ${ }^{71}$ Though there are scattered holdings implying the contrary, and though the recent case of Gideon $v$. Wainwright ${ }^{2}$ involving the amendment's right to counsel provision may presage an altered view, it seems that the federal constitution affords little redress to federal prisoners subjected to state detainers.

Even if the sixth amendment were held to be directly applicable to the states, it may fairly be doubted that it would substantially alter the constitutionality of delays in the trials of federal prisoners under state

cert. denied, 270 U.S. 657 (1926); cf. Boyce v. United States, 52 F. Supp. 115 (D. Pa. 1943); Marsino v. Higgins, 10 F.2d 534 (D. Mass. 1924), aff'd, 270 U.S. 627 (1926).

69 A similar statement must apparently now be made about article 14(a) of the Uniform Code of Military Justice, which provides that "under such regulations as the Secretary concerned may prescribe, a member of the Armed Forces accused of an offense against civil authority may be delivered, upon request, to the civil authority for trial." 70A Stat. 41 (1956), 10 U.S.C. $\$ 814$ (a) (1958). An earlier version of this provision was more positive in imposing a duty on military authorities. "When any person subject to military law, except one who is held by the military authorities to answer, or who is awaiting trial or result of trial, or who is undergoing sentence for a crime or offense punishable under these articles, is accused of a crime or offense committed within the geographical limits of the States of the Union and the District of Columbia, and punishable by the laws of the land, the commanding officer is required, except in time of war, upon application duly made, to use his utmost endeavor to deliver over such accused person to the civil authorities ... in order that he may be brought to trial. Any commanding officer who upon such application refuses or willfully neglects, except in time of war, to deliver over such accused person to the civil authorities... shall be dismissed from the service or suffer such other punishment as a court-martial may direct." 41 Stat. 803 (1920). Despite these provisions, it was held that state prosecutors are under no duty to request delivery of prisoners from military authorities on pain of dismissal for denial of speedy trial. People $v$. Maniatis, 297 IIl. 72,130 N.E. 323 (1921).

70277 U.S. 81 (1928).

71 United States ex rel. Von Cseh v. Fay (2d Cir. 1963); Odell v. Burke, 281 F.2d 782, 787 (7th Cir. 1960); Germany v. Hudspeth, 209 F.2d 15 (10th Cir. 1954); Ex parte Whistler, 65 F. Supp. 40 (D. Wis, 1945); Note, 57 Colum. L. REv. 846, 861 (1957). Compare Suit v. Ellis, 282 F.2d 145 (5th Cir. 1960).

72372 U.S. 335 (1963). 
detainers. The present federal cases require a delay of several years, the impairment of the defendant's opportunity to produce evidence, and a prior demand by the defendant for trial to raise even the possibility of a constitutional question. ${ }^{73} \mathrm{It}$ has been suggested that the prisoner is being denied equal protection of the law insofar as the right to speedy trial is denied categorically by the state to out-of-state prisoners. ${ }^{74}$ This argument seems tenuous. Whatever one may think of the cases declining to impose a duty of reasonable diligence ${ }^{75}$ upon state authorities in requesting prisoners detained elewhere, a distinction between in-state and out-of-state prisoners hardly seems unconstitutionally arbitrary where no duty to deliver the latter exists ${ }^{76}$ and where procedures for securing their delivery involve "a cumbersome special contract with the executive authority of the incarcerating state." 77

Notwithstanding the absence of federal constitutional obligation upon state officials to seek delivery of federal prisoners for trial, some state courts have begun to impose such an obligation under state statutes and constitutions. Speedy trial statutes requiring prisoners to be brought to trial within a specified number of days have been held to run during federal incarceration where no demand for delivery is made. ${ }^{78}$ In People v. Bryarly, ${ }^{79}$ the prosecutor was held to be under an obligation flowing

73 See notes 6-7 supra.

74 Note, 57 Colum. L. REv. 846, 862 n.114 (1957).

75 The "reasonable diligence" standard is proposed in Note, 57 Colum. L. REv. 846 (1957); Note, 61 Harv. L. Rev. 706 (1948); Note, 12 Rocky Mr. L. Rev. 214 (1940).

76 See Ponzi v. Fessenden, 258 U.S. 254 (1922).

77 Councl. of State Governments, Suggested State Legislation 81 (1957).

78 People v. Piscitello, 7 N.Y.2d 387, 165 N.E.2d 849 (1960). See People v. Swartz, 21 Ill. 2d 277, 171 N.E.2d 784 (1961); State v. Patton, 76 N.J. Super. 353, 184 A.2d 655 (1962); People ex rel. Lee v. Jackson, 131 N.Y.S.2d 278 (Glinton Co. Ct.), rev'd on other grounds, 285 App. Div. 33, 135 N.Y.S.2d 345 (1954); cf. People v. Taylor, indictment 581178, Criminal Court of Cook County Illinois, March 9, 1962 (Abraham W. Brussell, J.); State ex rel. Freedenberg v. Byrne, 20 Wis. 2d 504, 123 N.W.2d 305 (1963); see Walther, Detainer Warrants and the Speedy Trial Provision, 46 MARQ. L. REv. 423 (1963).

7923 Ill. 2d 313, 178 N.E.2d 326 (1961). See also State v. Duffy, 24 Conn. Supp. 308, 190 A.2d 243 (1963), where the court assumed without deciding that the state speedy trial statute might express a policy making mandatory a request for delivery of federal prisoners, but held that no duty to request existed where the state information and detainer were not filed until the day of the prisoner's scheduled release from federal prison. This result was reached in spite of the fact that the state had previously filed and dismissed an indictment and detainer based on charges which "may be assumed (to be) ... the same as those in the present information." Id. at $310,190 \mathrm{A.2d}$ at 244 . The court pointed out that the earlier charges were filed in another court and that there was "no determination there binding over said defendant to this court and the present criminal charges ... are in no sense a continuation of the charges that may have existed during defendant's federal detention." Care must thus be taken lest the nolle prosequi device vitiate even the most enlightened speedy trial rule. 
from the Illinois constitution to demand delivery of a prisoner incarcerated in a neighboring state.

The great weight of authority in state courts still holds, however, that state statutes and constitutional provisions do not require state prosecutors to demand federal prisoners for trial. ${ }^{80}$ Though some of these cases may turn on judicial findings that the prisoner failed to request trial, ${ }^{81}$ most rest on the proposition that a duty to demand cannot exist where there is no duty to surrender. ${ }^{82}$ In a single case where demand was made and refused, the state, as might have been expected, was held not barred from prosecution by the resulting delay. ${ }^{83}$

\section{Trial of State Prisoners on Chyarges in Other States}

The foregoing analysis of the obligations of state prosecutors and federal authorities to promote the speedy trial of federal prisoners under state detainer applies with equal force to speedy trial problems raised when the detainer system is employed between states. However, extradition legislation must be taken into account in this latter situation.

Article IV, section 2 of the Constitution provides:
A Person charged in any State with Treason, Felony or other Crime, who shall flee from Justice and be found in another State, shall on demand of the executive authority of the state from which he fled, be delivered up to be removed to the State having Jurisdiction of the Crime.

80 Ex parte Schechtel, 103 Colo. 77, 82 P.2d 762 (1938), criticized in Note, 12 Rockx MT. L. REv. 214 (1940), is a leading case. See also McCary v. Kansas, 281 F.2d 185 (10th Cir.), cert. denied, 364 U.S. 850 (1960); Petition of Yager, 138 F. Supp. 717 (D. Ky. 1956); Nolly v. State, 35 Ala. App. 79, 43 So. 2d 841 (1950); Ex parte Douglas, 54 Ariz. 322, 95 P.2d 560 (1939); Petition of Norman, 184 A.2d 601 (Del. 1962); McCloskey v. Director of Patuxent Institution, 230 Md. 635, 187 A.2d 833 (1963) (dictum); State v. Hall, 123 N.W.2d 116 (Minn. 1963); State v. Larkin, 256 Minn. 314, 98 N.W.2d 70 (1959); State v. Cochran, 366 S.W.2d 360 (Mo. 1963); People v. Zaffarano, 24 Misc. 2d 119, 208 N.Y.S.2d 200 (Queens Co. Ct. 1960); Auten v. State, 377 P.2d 61 (OkJa. Crim. App. 1962); Application of Melton, 342 P.2d 571 (Okla. Crim. App. 1959); Thompson v. State, 96 Okla. Crim. 8, 247 P.2d 535 (1952); Raine v. State, 143 Tenn. 168, 226 S.W. 189 (1920).

81 See Lee v. State, 185 Ark. 253, 47 S.W.2d 11 (1932); Kirby v. State, 222 Md. 421, 160 A.2d 786, cert. denied, 364 U.S. 850 (1960); Kirby v. Warden, 214 Md. 600, 133 A.2d 421 (1957).

82 See In re Schechtel, 103 Colo. 77, 82 P.2d 762 (1938).

83 People v. South, 122 Cal. App. 505, 10 P.2d 109 (1932). Some of the cases refusing to impose a duty on prosecutors to demand prisoners for trial go to incredible lengths. Thus in Application of Melton, 342 P.2d 571 (Okla. Crim. App. 1959), the court denied relief to a prisoner with the observation that the $\$ 330$ round-trip transportation cost involved would impose an unjust and unreasonable burden on the state. The court was careful to note that the one-way ticket required to bring the prisoner to Oklahoma at the expiration of his federal sentence would not constitute such a burden. Compare State ex rel. Fredenberg v. Byrne, 20 Wis. 2d 504, 123 N.W.2d 305 (1963). 
The provision was implemented by a contemporaneous federal statute enacted in 1793, which was carried over as section 3182 of the present criminal procedure provisions. ${ }^{84}$ The statute says "it shall be the duty of the executive authority of the state . . . to which [a] person has" fled to cause him to be arrested and secured and to cause notice of the arrest to be given to the executive authority making demand." This statute was largely vitiated by the decision of the Supreme Court in Kentucky $v$. Dennison ${ }^{85}$ which held that the states could not be coerced by federal courts into turning over fugitives, and that cooperation on their part was a matter of comity not of duty.

Following the Dennison decision, some state courts held that state governors, absent use of an outright pardon ${ }^{86}$ could not temporarily surrender prisoners to stand trial in other states without violating their duty to faithfully execute judicial sentences. ${ }^{87}$ The Uniform Criminal Extradition Act, ${ }^{88}$ promulgated in 1936 and since adopted in all but six states, ${ }^{89}$ was designed to meet the problem presented by these decisions. Section 5 of the act provides:

When it is desired to have returned to this state a person charged in this state with a crime, and such person is imprisoned or is held under criminal proceedings then pending against him in another state, the Governor of this state may agree with the Executive Authority of such other state for the extradition of such person before the conclusion of such proceedings or his term of sentence in such other state, upon condition that such person be returned to such other state at the expense of this state as soon as the prosecution in this state is terminated.90

The provision merely assures recalcitrant governors that they will not contravene their custodial duties by surrendering prisoners for trial since return of the prisoners may be provided for by agreement.91 In short, it approximates the effect of section 4085 of the Judicial Code on surrender of federal prisoners. Like its federal counterpart, it imposes no obligation

8418 U.S.C. § 3182 (1958).

8565 U.S. (24 How.) 66 (1860).

86 E.g., Opinion of the Justices, 201 Mass. 609, 89 N.E. 174 (1909).

87 E.g., In the Matter of Briscoe, 51 How. Pr. 422 (N.Y. Sup. Ct. 1876); Carpenter v. Lord, 88 Ore. 128, 171 Pac. 577 (1918); see In Matter of Troutman, 4 Zab. 634, 24 N.J.L. 634 (Sup. Ct. 1854).

889 U.L.A. at 258 (1957).

89 The act has not been adopted in the District of Columbia, Louisiana, Mississippi, Nevada, North Dakota, Puerto Rico, South Carolina and Washington.

80 9 U.L.A. at 295 (1957).

91 See Note, 48 Colum. L. Rev. 1190, 1205-06 (1948). 
on any state to invoke its benefits by demanding delivery of prisoners for trial.

It is highly doubtful that the sixth and fourteenth amendments impose any significant obligations on the states to demand prisoners held in other states for trial..$^{92}$ State speedy trial statutes are also frequently held not to run in relation to prisoners confined in other jurisdictions. ${ }^{93}$ Hence any duties that may be binding on state prosecutors to demand prisoners from other states ordinarily arise from state constitutions. Some state courts persist in demanding that their states must have an absolute right to prisoners before their prosecutors may be put under an obligation to request delivery.

Nevertheless about half of the reported cases on the point impose an obligation on the prosecuting state to demand delivery of the prisoner for trial by the imprisoning state. The conventional statements of the encyclopedia writers are apt to be especially treacherous and misleading here. ${ }^{94}$ There are cases like Traxler $v$. State, ${ }^{95}$ in which a thirteen year delay due to incarceration in another state was held not to amount to a denial of speedy trial where the prisoner made no demand. The court went so far as to hold that the statute of limitations did not run while the prisoner was outside the state. However, an Arkansas case denying the claimed right to speedy trial did so only because of the failure of the prisoner to demand trial, ${ }^{96}$ while a New Hampshire court in State $v$. Bugely ${ }^{97}$ denied a dismissal motion because of the prisoner's new alternative remedy under the Agreement on Detainers.

At least two state cases recognized the obligation on their prosecutors to request delivery of the out-of-state prisoner without the aid of a statute or the Agreement on Detainers. ${ }^{98}$ In the particularly thoughtful

92 Hoag v. New Jersey, 356 U.S. 464, 472 n.6 (1958). See textual discussion accompanying notes 70-77 supra.

93 Cf. Uniform Mandatory Dispostion of Detainers Act, 9B U.L.A. at 101 (Supp., 1963).

$9422 \mathrm{~A}$ C.J.S. Criminal Law $\S 472(2)(\mathrm{b})$ (1961): "The fact that the accused is confined in prison on another charge ordinarily is not good cause for a delay of the trial; but incarceration in the prison of another sovereign power may excuse delay in bringing the accused to trial."

9596 Okla. Crim. 231, 251 P.2d 815 (1952). See Cunningham v. State, 188 A.2d 359 (Del. 1962); People v. Peters, 198 Misc. 956, 101 N.Y.S.2d 755 (Columbia Co. Ct. 1951); Commonwealth v. Bressler, 194 Pa. Super. 208, 166 A.2d 549 (1960), cert. denied, 366 U.S. 932 (1961); cf. State v. Bugely, 103 N.H. 376, 172 A.2d 370 (1961); State v. Swain, 147 Ore. 207, 31 P.2d 745 (1934); Commonwealth v. Watson, 16 Pa. D. \& C.2d 190 (O. \& T. of Adams Co. 1959).

96 Pelligrini v. Wolfe, 225 Ark. 459, 283 S.W.2d 162 (1955).

97103 N.H. 376,172 A.2d 370 (1961).

98 People v. Bryarly, 23 IIl. 2d 313, 178 N.E.2d 326 (1961); People v. Brandfon, 157 N.Y.S.2d 864 (Ct. Spec. Sess. 1956). 
opinion in People v. Bryarly, the Illinois Supreme Court held that although the Illinois speedy trial statute applied in terms only to prisoners incarcerated in penitentiaries within the state, its policy was imported into the state constitutional provision so as to justify dismissal of an indictment where the prisoner had spent five years in a penitentiary in another state without a request for his delivery being filed by the Illinois authorities. Justice Schaefer observed:

The constitutional guaranty of a speedy trial contemplates that the means that are available to meet its requirements shall be utilized. Under the circumstances of this case we think that the burden of taking the steps necessary to bring about a prompt trial rested upon the People. When the legislature intended that a defendant should take affirmative action to prevent the delay of his trial, it expressly so provided. . . . Although the defendant wrongfully left the jurisdiction of the court, the prosecution knew where he was and could have initiated proceedings to return him to Illinois for trial. There is nothing to indicate that the Ohio authorities would not have acted favorably.99

\section{The Agreement on Detainers}

The proposed Agreement on Detainers, ${ }^{100}$ sponsored by the Council of State Governments and adopted in eight states ${ }^{101}$ provides two procedures for expediting the trial of prisoners on pending charges in other states. One may be invoked by the prisoner, the other by the prosecuting attorney of the demanding state.

Article III of the agreement outlines the prisoner-initiated procedure. The warden of the penitentiary is required to notify a prisoner of a detainer lodged against him "promptly" on receipt of the detainer.102 The warden is also required to "inform [the prisoner] of his right to make a request for final disposition of the indictment, information or complaint on which the detainer is based." 103 The prisoner may then make a de-

9823 Ill. $2 \mathrm{~d}$ at 319,178 N.E.2d at 330 . It may be noted that where a state surrenders a prisoner to another jurisdiction, where he is tried and incarcerated, and later attempts to regain him for a trial that could have been conducted before his surrender, the prisoner, apart from his right to speedy trial, may have a strong ground on which to resist extradition. See Taylor v. Taintor, 83 U.S. (16 Wall.) 366, 370 (1872). But this question usually can only be raised in the extraditing state. See People ex rel. Lee v. Jackson, 285 App. Div. 33, 135 N.Y.S.2d 345 (1954), aff'd, 309 N.Y. 676, 128 N.E.2d 322, cert. denied, 350 U.S. 893 (1955).

100 Council of State Governments, Suggested State Legislation 84-90 (1958) (hereinafter cited as Suggested LegisLation).

101 California (1963), Connecticut (1957), Montana (1963), New York (1957), New Jersey (1958), New Hampshire (1959), Pennsylvania (1959), Michigan (1961).

102 Article III(c), Suggested LegisLation at 85.

103 Ibid. 
mand for trial to the warden who in turn must forward the demand to the prosecuting authorities of the state filing the detainer. ${ }^{104}$ These authorities are directed to bring the prisoner to trial within 180 days of receipt of his petition on all charges, pending in the state, for which detainers have been received and on which the prisoner has demanded a trial.105 If the prisoner is returned to the original place of imprisonment without trial on any such charges, they are to be dismissed with prejudice. ${ }^{106}$ Demands filed by prisoners under article III operate as a waiver of extradition by the prisoner and "a consent by the prisoner to the production of his body in any court where his presence may be required . . .."107

Article IV provides for a separate procedure for delivery of prisoners on the initiative of prosecutors. A prosecutor who has filed a detainer against the prisoner may transmit to the prison authorities a request for production of the prisoner, such request having been approved by a court having jurisdiction to try the charge on which the detainer is based. 108 The prison authorities are required to notify all other prosecutors in the state from which the demand is received who have lodged detainers against the prisoner that the prisoner is being made available. ${ }^{109}$ The prisoner must be brought to trial within 120 days of his arrival in the receiving state. ${ }^{110}$ In deference to traditional conflicts principles, article IV (a) ${ }^{111}$ provides for a thirty day delay upon receipt of a request to deliver a prisoner within which period the governor of the "sending state" may disapprove the request either upon his own motion or upon the motion of the prisoner. Article IV(d) further provides that the prisoner retains his right to contest extradition, but delivery "may not be opposed or denied on the ground that the executive authority of the sending state has not affirmatively consented to or ordered such delivery." 112

Article V, subsections (a) and (c), ${ }^{113}$ the core of the agreement, provide:

(a) In reponse to a request made under Article III or Article IV

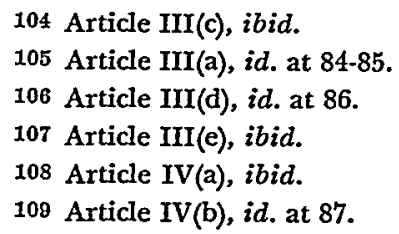

110 Article IV(c), ibid. Both this provision and article.III(a), id. at 85, qualify the time limit for trial in the receiving state as follows: "[F]or good cause shown in open court, the prisoner or his counsel being present, the court having jurisdiction of the matter may grant any necessary or reasonable continuance."

111 Id. at 86 .

112 Id. at 87.

$113 \mathrm{Id}$. at 87-88. 
hereof, the appropriate authority in a sending state shall offer to deliver temporary custody of such prisoner to the appropriate authority in the state where such indictment, information or complaint is pending against such person in order that a speedy and efficient prosecution may be had.

(c) If the appropriate authority shall refuse or fail to accept temporary custody of said person, or in the event that an action on the indictment, information or complaint on the basis of which the detainer has been lodged is not brought to trial within the period provided in Article III or Article IV hereof, the appropriate court of the jurisdiction where the indictment, information or complaint has been pending shall enter an order dismissing the same with prejudice, and any detainer based thereon shall cease to be of any force or effect.

Thus when a detainer is lodged, the prisoner may demand trial under article III. If the imprisoning state authorities refuse to yield his temporary custody to the state which filed the detainer, the mandatory language of article $V(a)$ would seem to support a suit for mandamus by the prosecuting state and perhaps by the prisoner as well to compel the prisoner's temporary release. If the prosecuting state refuses to accept and try the demanding prisoner, article $V(c)$ would command dismissal of the charge. ${ }^{114}$ Similarly, when a detaining prosecutor demands custody

114 Article $V(c)$ could also be read to provide that whenever a prosecuting state failed to try the prisoner within the time limit specified in article III (180 days after prisoner demand) the charge must be dismissed. Thus dismissal might result when the imprisoning state authorities refused to yield custody and mandamus proceedings resulted in delay of receipt of custody beyond the 180-day limit. Presumably such delays, or unavoidable administrative delays should not result in a form of punishment for the prosecuting state.

This ambiguity concerning sanctions for failure to deliver was recognized by a New Jersey court in State v. West, 79 N.J. Super. 379, 191 A.2d 758 (App. Div. 1963), where an attempt was made to have a New Jersey court discharge from confinement a prisoner held for extradition to Pennsylvania after his New Jersey jailor failed to honor the prisoner's article III demand that he be delivered to Pennsylvania for trial prior to expiration of his New Jersey sentence. The court held that New Jersey was bound to deliver the prisoner to Pennsylvania by reason of the Uniform Criminal Extradition Act, on a showing that a valid indictment was outstanding in Pennsylvania, and that the Agreement on Detainers did not expand the authority of New Jersey courts to scrutinize the validity of indictments in other states. The court avoided deciding whether "since the warden of the New Jersey institution failed to fulfill the duties cast upon him by the statute ... Pennsylvania must suffer the consequences of this ommission ...." 79 N.J. Super. at 386, 191 A.2d at 762. The court also held, more dubiously, that by virtue of article III(e) a prisoner's request for delivery could operate as a waiver of extradition proceedings even where that request was not acted upon.

In People v. Esposito, 37 Misc. 2d 386, 238 N.Y.S.2d 460 (Queens Co. Ct. 1960), a similar failure by a New Jersey warden to forward a prisoner's request to New York authorities in proper form with a certificate showing the details of the New Jersey sentence and an offer to deliver up the prisoner resulted in dismissal of the New York charge. There, however, the New York prosecutor had notice of the prisoner's request 
under article IV, he (or perhaps the prisoner) could obtain an order for release under article $V(a)$. If the executive authority of the prison state refuses to allow the prisoner's release in response to the article IV demand, the prisoner could still initiate an article III proceeding. Thus it appears desirable to maintain article III alongside article IV. Technical problems of timing may arise if both articles are invoked simultaneously, since under article III the prisoner must be brought to trial 180 days after making his demand while article IV requires that trial commence 120 days after the prisoner is received in the demanding state. These conflicts could be resolved by imposing whichever limit is shorter.

The agreement as drafted, would do much to clear up technical obstacles to speedy trial, after the filing of detainers on defendants incarcerated either in federal or state prisons. ${ }^{115}$ The agreement contemplates federal enactment, ${ }^{116}$ though Congress has not yet made it binding on federal prosecutors.117

The agreement falls short as an effective guarantee of speedy trial for incarcerated defendants insofar as it fails to require the prosecutor to

and failed to vigorously press efforts to secure his delivery, save by a belated article IV proceeding which the court held could not operate to deprive the prisoner of his article III rights. The warden's failure to attach the appropriate certificates did not vitiate the prisoner's request since "the whole purpose of the certificate seems to have been to assure the District Attorney of sufficient information to enable him to make an intelligent decision as to whether to 'drop the detainer immediately, without additional correspondence back and forth." "37 Misc. 2d 395 n.8, 238 N.Y.S.2d at 468 n.8.

115 Some state courts thus far applying the agreement have given it a broad construction. State v. Chirra, 79 N.J. Super. 270, 191 A.2d 308 (L. 1963); cases cited and discussed note 114 supra. This approach would seem necessary if the agreement is to be effective, since its processes may be called into motion by prisoners themselves.

116 Article II(a), SUGgested LEgisLATton at 84, provides: " 'State' shall mean a state of the United States, the United States of America; a territory or possession of the United States; the District of Columbia; the Commonwealth of Puerto Rico." Article $\mathrm{V}$ (a) includes a special provision for federal prisoners: "In the case of a federal prisoner, the appropriate authority in the receiving state shall be entitled to temporary custody as provided by this agreement or to the prisoner's presence in federal custody at the place for trial, whichever custodial arrangement may be approved by the custodian." $I d$. at 87-88. This section codifies the suggestion of the Ponzi case relating to custody of federal prisoners released for trial. Because of a general federal statute relating to interstate compacts dealing with criminal procedure, congressional ratification of the agreement is not needed to make it effective as between states ratifying it. NATL. CoNF. OF Comm'rs on UNIForm STate Laws, Handbook 208 (1962). The federal statute is 4 U.S.C. \&111(a) (1958), which provides that "the consent of Congress is hereby given to any two or more States as to enter into agreements or compacts for cooperative effort and mutual assistance in the prevention of crime and in the enforcement of their respective criminal laws and policies ...." See Grad, Federal-State Compact: A New Experiment in Cooperative Federalism, 63 CoLum. L. REv. 825 (1963). Some states allow their governors to enter compacts for crime prevention and punishment without legislative approval. See, e.g., IL.L. REv. STAT. ch. 38, \$ 818 (1963).

117 A bill (H.R. 8365) which would make the agreement binding against federal prosecutors was introduced by Congressman Celler on September 10, 1963. 
demand temporary release of the prisoner for trial. Addition to article IV of a section making dismissals mandatory where prosecutors who have filed detainers fail to request custody would be desirable in order to protect the interests of prisoners who fail to effectively assert their article III rights from inadvertance rather than choice. The suggested addition to article IV would deny prisoners an opportunity to gamble that detainers may be lifted and charges dropped prior to expiration of their terms. But it is not clear that they should have this opportunity, and its loss would seem a small price to pay for the preservation of speedy trial without reliance on the prisoner's own efforts, for the greater inducement to efficiency in prosecutor's offices and for maintenance of discretion to impose concurrent sentences ${ }^{118}$ upon the defendant.

\section{Conclusion}

Enactment of the Agreement on Detainers, as drafted, by the states and the federal government will go far toward removing technical roadblocks to speedy trial of a prisoner against whom a detainer has been lodged. The article III requirement that prisoners be notified of detainers filed against them and of their rights under the agreement should prove useful. However the agreement undesirably omits any requirement that the prosecutor demand custody of the prisoner once a detainer has been filed, and it does not require the filing of detainers once a prisoner has been charged in another jurisdiction. Thus passage of the agreement should be coupled with development of state and federal speedy trial standards of the Bryarly type requiring dismissal of charges when custody of the charged prisoner for trial is not demanded. The mandate of any effective procedure to insure speedy trial for the prisoner must be aimed directly at prosecutors and not made dependent upon the prison letter box.

118 Article III(e): "The request for final disposition shall also constitute a consent by the prisoner to the production of his body in any court where his presence may be required .... and a further consent voluntarily to be returned to the original place of imprisonment. . . Nothing in this paragraph shall prevent the imposition of a concurrent sentence if otherwise permitted by law." SugGESTED LEgISLATION at 86 . Where a statute sets a minimum prison term, failure to accord a prisoner a speedy trial of course prevents the second sentencing judge from either achieving or approximating the results of a concurrent sentence.

Article 14(b) of the Uniform Code of Military Justice, interestingly, explicitly seeks to prevent concurrent sentencing. "When delivery under this article is made to any civil authority of a person undergoing sentence of a court-martial, the delivery if followed by conviction in a civil tribunal, interrupts the execution of the sentence of the court martial, and the offender after having answered to the civil authorities for his offense shall, upon the request of competent military authority, be returned to military custody for completion of his sentence." 70 A Stat. 41 (1956), 10 U.S.C. § 814(b) (1958). See Edwards v. Madigan, 281 F.2d 73 (9th Cir. 1960). 